\title{
Application of Task-driven Teaching Model in Teaching Reform and Practice of Mechanical CAD/CAM Technology
}

\author{
Wan Fangfang 1,a Yao Bin 1,b \\ 1Medical College of Xi'an Peihua University \\ Xi'an, Shaanxi Province 710100, P.R. China \\ a729655504@qq.com, byancong192@qq.com
}

\begin{abstract}
Aiming at the characteristics of mechanical CAD/CAM technology in mechanical engineering courses in colleges and universities, this paper analyzes the three main problems existing in the course of traditional teaching, studies and explores the major ideas to solve the problems, and puts forward the teaching mode based on task-driven. The teaching mode is applied to the teaching reform and practice of the course. This paper focuses on the task design, task implementation and task summary in the task-driven teaching model, the application of three steps in the teaching reform and practice of mechanical CAD/CAM technology. The task-driven teaching mode enables teachers and trainees to connect with each other through tasks. The teaching process takes task as the main line, and the task corresponds to the teaching link. Therefore, in the course of learning, the actual task of exploration of learning can greatly stimulate students ' interest in learning and curiosity, making learning more effective.
\end{abstract}

Keywords-CAD/CAM Technology; Task-driven; Teaching Reform

\section{INTRODUCTION}

Mechanical CAD/CAM technology is one of the specialized elective courses of students who major in mechanical engineering. It aims at the operation of $3 \mathrm{~d}$ modeling software, Inventor, with strong theoretical, applied and practical system [1]. The learning effect is related to the follow-up professional courses of study and graduation design [2]. However, with the continuous reform of school curriculum in recent years, many courses have greatly reduced their hours of study, and this course is no exception. Taking our school as an example, mechanical CAD/CAM technology for mechanical engineering major is 20 school hours and 20 school hours of practical training. For teachers, how to organize the book knowledge teaching in a short time and improve students' CAD application ability is a problem we have to face. To this end, this paper analyzes the main problems existing in the teaching of the traditional mechanical CAD/CAM technology. Research and explores the main train of thought to solve the problem, and it has carried out the teaching reform and practice research based on task drive "mechanical CAD/CAM technology" [3].

\section{ANALYSIS OF PROBLEMS EXISTING IN THE TEACHING OF TRADITIONAL MECHANICAL CAD/CAM TECHNOLOGY}

Problem one is lacking of engineering background. The mechanical CAD/CAM technology involves extensive engineering background, but in the teaching and examination the students are demanded to master the operation methods and techniques, with the introduction of the engineering application background not detailed enough. Students is difficult to clearly understand the background of modeling equipment, and don't know what modeling object in actual equipment has applications [4], resulting in the dull, modeling techniques and modeling process modeling isolation between means and methods, making the students lose their learning initiative and enthusiasm, will only passively memory and operating skills, and can not make teaching to achieve the desired effect.

Problem 2. Lack of a review of basic drawing knowledge. "Mechanical drawing" school courses sharply reduce, leads to that the basic knowledge of drawing of students is relatively weak now. Especially in the image recognition there are great differences on the ability of reading. Students cannot be formed in the mind quickly three-dimensional models of objects. Students' knowledge of mechanical drawing will directly influence the learning effect of mechanical CAD/CAM technology. Teachers in the teaching process in the traditional teaching tends to ignore the problem, and did not know before teaching students to master the required knowledge of drawing of degree. They did not timely review of drawing in the process of teaching knowledge, thus effects the teaching effect.

Problem 3. Lack of motivation for active learning. In the traditional mechanical CAD/CAM technology "course teaching, ignoring the students' main body status and differences in education. Students in the initiative and creativity can not get to play in the process of teaching, and students easily satisfied with" the teacher told students "passive learning. Quite a number of students in this teaching environment can understand the content of the teacher speak in class, but everywhere go wrong in their own independent drawing class. The root of the problem is that the teaching is a kind of passive teaching for students, and students lack active learning of driving force. 
by exploring problems [6]. The key is to design the teaching task which on the one hand can close ties between the teaching of knowledge and skills students need to master, on the other hand, has certain equipment background, exploratory and creative. Through the task-driven teaching method, students can learn with practical tasks in exploration and stimulate their interest and thirst for knowledge in learning, so as to obtain better learning results. According to the teaching object and the course of this course, a series of reforms have been carried out in the teaching of mechanical CAD/CAM technology by using task-driven method. The application of Task-driven Teaching Model in curriculum is summarized as three steps: The design of the task, Task implementation and Task conclusion. The three steps of the task are related to teaching links and teacherstudent activities, and their relations are shown in Table I . combination of students' learning activities and tasks, so as to guide and maintain students' learning interest and motivation

TABLE I. THE RELATIONSHIP BETWEEN THE THREE STEPS OF TASKS AND TEACHING LINKS, TEACHER-STUDENT ACTIVITIES

\begin{tabular}{|c|c|c|c|}
\hline Step & 1 & 2 & 3 \\
\hline Task & The design of the task & Task implementation & Task conclusion \\
\hline Teacher & $\begin{array}{l}\text { Analysis of teaching content, } \\
\text { determination of teaching } \\
\text { objectives, determination of } \\
\text { teaching difficulties and } \\
\text { determination of teaching process. }\end{array}$ & $\begin{array}{llr}\text { Create } & \text { situations, } & \text { analyze } \\
\text { tasks, counselling } & \text { and } \\
\text { answering questions. } & \end{array}$ & $\begin{array}{l}\text { Summing up, evaluating, } \\
\text { extracting knowledge points. }\end{array}$ \\
\hline Students & Pre class Preview & $\begin{array}{lrr}\begin{array}{l}\text { Clear objectives, } \\
\text { tasks, collect }\end{array} & \begin{array}{r}\text { identify } \\
\text { resources, } \\
\text { explore }\end{array} \\
\begin{array}{l}\text { Consultation } \\
\text { implementation of a task }\end{array} \\
\end{array}$ & $\begin{array}{l}\text { Display results, collective } \\
\text { communication, }\end{array}$ \\
\hline Teaching links & Instructional design & New knowledge learning stage & $\begin{array}{l}\text { the task ending and the } \\
\text { consolidation of new } \\
\text { knowledge }\end{array}$ \\
\hline
\end{tabular}

\section{A. The design of the task}

For teaching reform based on task drive of "mechanical $\mathrm{CAD} / \mathrm{CAM}$ technology" course, one of the most important is to design task, and design of the task must have equipment background, the characteristics of the pertinence and practicability. In accordance with the classroom teaching content, teaching target, teaching emphasis, teaching difficulties, which the syllabus and textbooks determine, design tasks should cover teaching content, show the teaching goal, outstand teaching important points and break through the teaching difficulties [7]. For example, in the process of learning creating and editing features, the difficulty of learning is to master the creation of various features and the application scenes of various features. Usually, teachers will use many models to give examples to explain the creation of features one by one, but the characteristics are lack of relevance. And the task driven method is adopted, it can be assumed that a certain type of Russian equipment has a special part fault, and there are insufficient spare parts, which need to be redesigned for replacement. But also can be different in learning knowledge in the same task to carry out the teaching design, and can complete the same model with different modeling and skills, get analysis and comparison of different modeling methods in the same task for their respective advantages and disadvantages, and make students better grasp and apply what they have learned knowledge and modeling.

In addition, teachers should reasonably set general tasks and sub-tasks according to the teaching chapters, and design different sub-tasks in different levels and stages according to the general tasks designed. From the perspective of the learning process of students, after finished a task, will generate new cognitive requirements. Faculty, according to the hierarchy of knowledge, design a new task with both learned knowledge, and have to join the new knowledge, to make the students both review consolidate learned knowledge in the process of completing the task, and learning, explore new knowledge, step by step, step by step to complete the task, gradually increase. For example design of a certain type of Russian equipment, assign the modeling part of the overall task to the creation and editing of the second chapter of the draft diagram and the third 
chapter features the creation and editing of these two chapters sub-tasks. The assembly of the model is assigned to chapter 5 and the generation of engineering drawing can be assigned to the engineering drawing of chapter 6. Overall design of the curriculum is shown in Table II

TABLE II. OVERALL DESIGN OF THE CURRICULUM

\begin{tabular}{|c|c|c|c|}
\hline Task & Sub task & Chapter & Period \\
\hline \multirow{2}{*}{$\begin{array}{l}\text { Establishing equipment } \\
\text { model }\end{array}$} & $\begin{array}{l}\text { Analysis of characteristics and set up } \\
\text { sketchs of equipment model }\end{array}$ & $\begin{array}{l}\text { Chapter } 2 \text { :The creation and } \\
\text { editing of sketches }\end{array}$ & 4 \\
\hline & $\begin{array}{l}\text { Setting up equipment models by various } \\
\text { methods }\end{array}$ & $\begin{array}{l}\text { Chapter } 3 \text { :The creation and } \\
\text { editing of feature }\end{array}$ & 4 \\
\hline \multirow{2}{*}{$\begin{array}{l}\text { Assembly } \\
\text { model }\end{array}$} & $\begin{array}{l}\text { Assemble the equipment model into a } \\
\text { ligands }\end{array}$ & Chapter 4 :The Assembly design & 4 \\
\hline & $\begin{array}{l}\text { Motion simulation of the equipment } \\
\text { model }\end{array}$ & Chapter 5 : The Visual design & 4 \\
\hline $\begin{array}{l}\text { Generating equipment } \\
\text { engineering drawing }\end{array}$ & $\begin{array}{l}\text { creating the drawings of the equipment } \\
\text { assembly body and the drawings of the } \\
\text { main parts }\end{array}$ & $\begin{array}{l}\text { Chapter } 6: \text { The engineering } \\
\text { drawing }\end{array}$ & 4 \\
\hline
\end{tabular}

\section{B. Task implementation}

Task implementation is the key to ensure the effect of the course teaching reform of mechanical CAD/CAM technology. In the process of task implementation, analysis tasks, the anatomy of the task and explain mission is key to stimulate students' learning interest in the task, training initiative of learning. Faculty first task force to guide students to preliminary thinking of the mission, to understand the difficulty and key steps in the mission and then through the interactive analysis of concrete construction points discussed with students, order, procedures and methods for the demo operation methods and techniques of each command. In the process of student operation, according to the nature of the task, a variety of forms are adopted to complete the task. The form of autonomous learning, can be used independently, makes the students into full play and creativity, excavate the potential of students and cultivate the students' self-study ability. Stimulate students' spirit for the purpose. It also be used to assist learning, the collective to complete. Grouped according to the level of the students and special collocation, cultivate students thinking from various angles, the ability to analyze and solve problems through the exchanges, communication, projects, cooperation and mutual assistance.

In the process of organizing students to complete the task, the teacher should give guiding help. As for the common problems of students, we should guide them to solve them and help them grasp the important and difficult points of learning through proper explanation. For example, the task in the students, according to students' questions, proper analysis of the main characteristics of the equipment and use the modeling method, when students complete a task, to focus on key and difficult to make more students master the task according to the common problems encountered in the process of students. At the same time, the teaching principle of "teacher-led and student-led" is fully followed. In the process of task implementation, the teacher is the organizer and guide. In the process of completing the task, students should be given appropriate guidance and help. A teacher cannot assign tasks without regard to the students, nor can he delegate tasks to the students.

\section{Task conclusion}

Task end is often considered as the end of the task driven teaching but task summary exactly is actually the most which can not be ignored part of the course teaching reform. This link is carried out or not and the implementation will directly affect the teaching effect [8]. First of all, analyze and sort out the key or easy problems that lead to the failure of the task in the process of carrying out the task by summarizing the task, and make targeted corrections and explanations. In particular, we should pay attention to the modeling method of the specific characteristics of the equipment in the modeling process and the assembly method of complex parts in the assembly process. Secondly, through the task summary to timely correct students unreasonable modeling operation habits and the importance of standardized and reasonable operation of drawing software is explained. Contrast groups in the process of summarizing or representative of the modeling and assembly method of the classmate, analysis of the pros and cons of various methods. The same feature of a part may have different modeling sequence modeling methods, and the same assembly has different assembly order and constraint method in assembly. The different methods have the appropriate situations. The students need to pay attention to the distinction. By explaining the advantages and disadvantages of these different methods, 
the teacher can help students reasonably choose the appropriate method according to the actual model.

To objectively evaluate the situation of students to complete the task will effectively improve the enthusiasm of students to carry out the task. Positive evaluation will strengthen students' independent thinking ability and cooperation ability, so as to arouse the enthusiasm of students, to effectively improve the teaching effect.

\section{CONCLUSION}

The teaching content of CAD courses is highly operable, which aims to cultivate students' practical ability. The taskdriven teaching mode is very suitable for the practical teaching content. This paper expatiates the main problems of the teaching of mechanical CAD/CAM technology, and the understanding of the task driven teaching mode. On the basis of it, we get three steps of the teaching mode of task driving task design, task implementation, task summarizes. It corresponds to the teaching of teaching design, learning new knowledge, consolidate the new knowledge of the three stages of learning. In each step of the specific, application methods are given. It has strong applicability and can effectively improve the learning effect of students.

\section{REFERENCES}

[1] Xin-liang Cao. Teaching mode reform and practice in local colleges and universities "during the transitional period of the project task drive" with the development of electronic information engineering undergraduate engineering quality cases $[\mathrm{J}]$. Journal of education modernization, 2015.6:6-9. (In Chinese)

[2] Cheng-qin Zhao. Research and practice of CAD teaching by task driven method [J]. Journal of engineering graphics, 2009,30 (S1):121-125. (In Chinese)

[3] [us] Howard Gardner. Translated by Zhi-long Shen. Intelligent structure [M]. Zhejiang people's publishing house, 2013.

[4] Min Zhang. Implementation of task-driven teaching method in computer teaching [J]. Electronic production, 2015.4. (In Chinese)

[5] Jin Li-zheng. The advantages and implementation of task driven in improving the status of college students as the main body [J]. Journal of Hangzhou Insitute of Electronic and Technology, 2001, (2): 55-58. (In Chinese)

[6] Qin-bao Hou. Research on the design mode of "task driven method" in Computer Teaching[J]. Coal technology, 2005(6):113. (In Chinese)

[7] Ren-yan Min. Research on the importance and training strategy of College Students' professional quality [J]. Education and profession, 2010(6). (In Chinese)

[8] Bao-rong Wan. Research on the interesting teaching of mechanical CAD driven by task [J]. Occupation, 2011( 6) : 30 -31. (In Chinese) 